\title{
SISTEM INFORMASI LEMBAGA PEMASYARAKATAN \\ Studi Kasus : Lembaga Pemasyarakatan Kelas IIB Kota Garut
}

\author{
${ }^{1}$ Dian Nurdiana ${ }^{2}$ Andri Suryadi \\ ${ }^{12}$ Program Studi Pendidikan Teknolgi Informasi, Fakultas Ilmu Sains dan Terapan \\ Institut Pendidikan Indonesia \\ 1 1 andrisuryadi@institutpendidikan.ac.id \\ 22diannurdiana@institutpendidikan.ac.id
}

\begin{abstract}
Penitentiary is a place to guide prisoners in Indonesia. At the Garut Class IIb Correctional Institution, the data collection process and data recapitulation of prisoners is done manually. In a sense, data collection of prisoners is carried out by recording prisoners' data into general ledger and data on leave or conditional release data is recorded in the guidance book. Then in carrying out the data recapitulation of prisoners, officers must first classify the data of prisoners first, after the data is finished grouped, then the officer will make the recapitulation results into Microsoft Excel, then the data is presented to the leader or posted on the writing board in graphical form. As well as for data collection, visitors are recorded in the visit list book, so to find out information on the visit record, the officer needs a long time. This process can be said to be a manual process. From these problems the author intends to help create a program entitled "Information System for Correctional Institutions Case Study of Class IIB Correctional Institution in Garut City".
\end{abstract}

Keywords: Correctional Institution, Information System.

\begin{abstract}
ABSTRAK : Lembaga pemasyarakatan adalah sebuah tempat untuk melakukan pembinaan terhadap narapidana di Indonesia. Pada Lembaga Pemasyarakatan Kelas IIb Kota Garut saaat ini proses pendataan dan rekapitulasi data narapidana dilakukan secara manual. Dalam arti, pendataan data narapidana dilakukan dengan cara mencatat data narapidana ke dalam buku besar dan pendataan data cuti atau pelepasan bersyarat dicatat ke dalam buku pembinaan. Kemudian dalam melakukan rekapitulasi data narapidana, petugas harus mengelompokan data-data narapidana terlebih dahulu, setelah data selesai dikelompokkan, maka petugas akan membuat hasil rekapitulasi kedalam Microsoft Excel, kemudian data tersebut disajikan kepada pemimpin atau ditempel dipapan tulis dalam bentuk grafik. Serta untuk pendataan data pengunjung dicatat ke dalam buku daftar kunjungan, jadi untuk mengetahui informasi catatan kunjungan, petugas membutuhkan waktu yang cukup lama. Proses tersebut bisa dikatakan sebagai proses manual. Dari permasalahan-permasalahan tersebut penulis bermaksud membantu membuatkan program yang berjudul "Sistem Informasi Lembaga Pemasyarakatan Studi Kasus Lembaga Pemasyarakatan Kelas IIB Kota Garut".
\end{abstract}

Kata Kunci: Lembaga Pemasyaratkatan, Sistem Informasi.

\section{PENDAHULUAN}

\subsection{Latar Belakang}

Manfaat dengan adanya teknologi informasi menjadikan suatu hal menjadi efektif dan efisien. Namun, hal itu belum dirasakan oleh beberapa instansi pemerintahan. Salah satu contohnya pada saat pengelolaan data lembaga pemasyarakatan yang masih menggunakan sistem manual. Sistem manual tersebut menjadi kendala dalam beberapa hal seperti pemasukan data, waktu pemeriksaan dan waktu pengumuman data lapas. Kendalakendala tersebut seharusnya dapat diatasi dengan pemanfaatkan teknologi informasi karena salah satu tujuan dengan adanya teknologi informasi adalah untuk menjadikan hal menjadi efektif dan efisien.

Dengan adanya perkembangan teknologi informasi haruslah ada solusi terhadap masalah pengelolaan data pemerintah, salah satunya lembaga pemasyarakatan kepolisian. Salah satu solusi yang dapat 
ditawarkan adalah dengan membuat sistem pengeloaan data dengan aplikasi yang secara offline taupun online. Sistem pengelolaan data ini dapat menjadikan solusi bagi masalah-masalah yang selama ini terjadi seperti pemasukan data tahanan yang sesuai data pribadinya yang bisa diketahui secara cepat, karena di integrasikan dengan data lainnya, dengan sistem keLembaga Pemasyarakatan Studi Kasus Lembaga Pemasyarakatan Kelas IIB Kota Garut".

\subsection{Rumusan Masalah}

Bagaimana membuat Sistem Informasi Lembaga Pemasyarakatan di Lembaga Pemasyarakatan Kelas Iib Kota Garut..

\subsection{Batasan masalah}

Dalam penelitian Sistem Informasi Lembaga Pemasyarakatan, peneliti memberi batasan masalah yaitu data yang digunakan bersumber dari data buku besar dan buku pembinaan Lembaga Pemasyarakatan Kelas Iib Kota Garut.

\subsection{Tujuan Penulisan}

Tujuan penulisan ini adalah membuat Sistem Informasi Lembaga Pemasyarakatan di Lembaga Pemasyarakatan Kelas IIB Kota Garut.

\subsection{Manfaat}

Penulisan ini diharapkan dapat dijadikan sebagai informasi dan bahan pertimbangan bagi petugas dalam melakukan pendataan dan rekapitulasi data narapidana di Lembaga Pemasyarakatan Kelas IIB Kota Garut.

\section{KAJIAN TEORI}

\subsection{Lembaga Pemasyarakatan}

Lembaga Pemasyarakatan disingkat LP atau LAPAS adalah tempat untuk melakukan pembinaan terhadap Sebelum dikenal istilah lapas di Indonesia, tempat tersebut disebut dengan istilah penjara. Lembaga Pemasyarakatan merupakan Unit Pelaksana Teknis di bawah Direktorat Jenderal Pemasyarakatan Kementerian Hukum dan Hak Asasi Manusia (dahulu Departemen Kehakiman). Pegawai negeri sipil yang menangangi pembinaan narapidana dan tahanan di lembaga pemasyarakatan disebut dengan petugas pemasyarakatan, atau dahulu lebih di kenal dengan istilah sipir penjara.

\section{Narapidana}

Narapidana adalah seorang yang melakukan tindakan kriminal atau melanggar hukum dan dinyatakan bersalah oleh pengadilan dan harus menjalani hukuman. Selama kesalahan seorang pelaku kriminal belum ditetapkan oleh seorang hakim, maka pelaku kriminal disebut dengan terdakwa.

\section{Pembebasan Bersyarat (PB)}

Pembebasan Bersyarat adalah proses pembinaan Narapidana di luar Lembaga Pemasyarakatan setelah menjalani sekurang-kurangnya $2 / 3$ (dua pertiga) masapidananya minimal 9 (sembilan) bulan.

\section{Hukum Pidana}

Hukum Pidana adalah keseluruhan dari peraturanperaturan yang menentukan perbuatan apa yang dilarang dan termasuk kedalam tindak pidana, serta menentukan hukuman apa yang dapat dijatuhkan terhadap yang melakukannya.

\section{METODE REKAYASA}

\subsection{Analisis Sistem}

Analisis sistem merupakan uraian dari sistem yang utuh ke dalam bagian-bagian komponennya dengan maksud untuk mengidentifikasi dan mengevaluasi permasalahan. Bagian analisis ini terdiri atas analisis fungsional dan analisis non fungsional.

\subsection{Kebutuan Fungsional}

Kebutuhan fungsional mengidentifikasi proses-proses dan informasi apa saja yang nantinya dihasilkan oleh aplikasi.

\subsection{Kebutuhan Non Fungsional}

\section{Perangkat Keras}

Perangkat keras (hardware) adalah peralatan dalam komputer yang secara fisik dapat dilihat.

\section{Perangkat Lunak}

Perangkat lunak dalam sistem komputer merupakan serangkaian perintah dengan aturan tertentu yang mengatur operasi perangkat keras.

\subsection{Alur Sistem}

Adapun alur proses narapidana dan alur proses pengunjung sebagai berikut :

\section{a. Alur Proses Narapidana}




\begin{tabular}{|l|c|c|}
\hline PENGUNJUNG & PETUGAS & NAPI \\
\hline $\begin{array}{c}\text { Data } \\
\text { pengunjung }\end{array}$ & \multicolumn{1}{|c|}{$\begin{array}{c}\text { Pendataan } \\
\text { Pengunjung }\end{array}$} & \\
\hline & & \\
\hline $\begin{array}{c}\text { Pengecekan } \\
\text { barang }\end{array}$ & Bertemu napi \\
\hline
\end{tabular}

Gambar 1. Model bisnis narapidana

Alur dari gambar 1 adalah narapidana masuk kemudian petugas mendata biodata narapidana, setelah data masuk, data tersebut menjadi data narapidana. Narapidana menjalani hukuman dan mendapat pembinaan dari lembaga pemasyrakatan. Petugas kemudian merekap data narapidana dengan memasukkan data-data narapidana. Sedangkan pemimpin dapat melihat hasil rekapitulasi yang ditampilkan dengan grafik batang.

\section{b. Alur Proses Pengunjung}

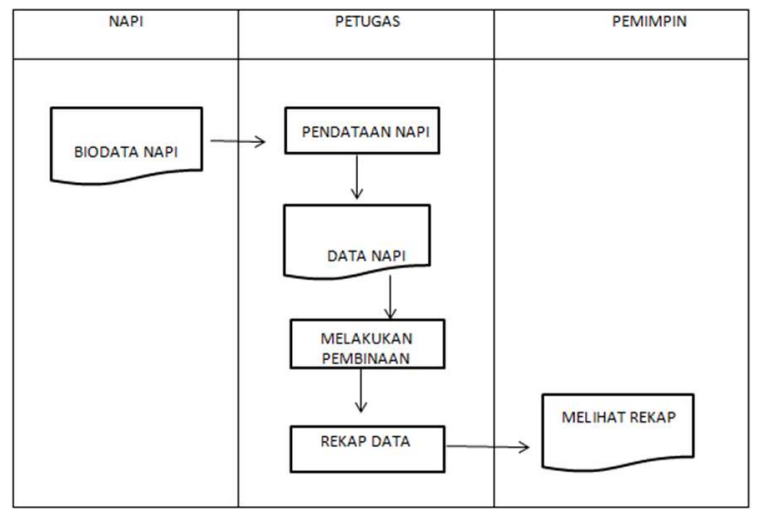

Gambar 2. Model bisnis pengunjung

Alur dari gambar 2 adalah ketika pengunjung datang, petugas memasukkan data atau mendata pengunjung, setelah data pengunjung disimpan, akan menjadi data pengunjung. Kemudian pengunjung akan masuk ke ruang pengecekan. Setelah petugas melakukan pengecekan barang kepada pengunjung, selanjutnya pengunjung dapat bertemu narapidana.

\subsection{Desain Sistem}

\section{Proses Hierarki}

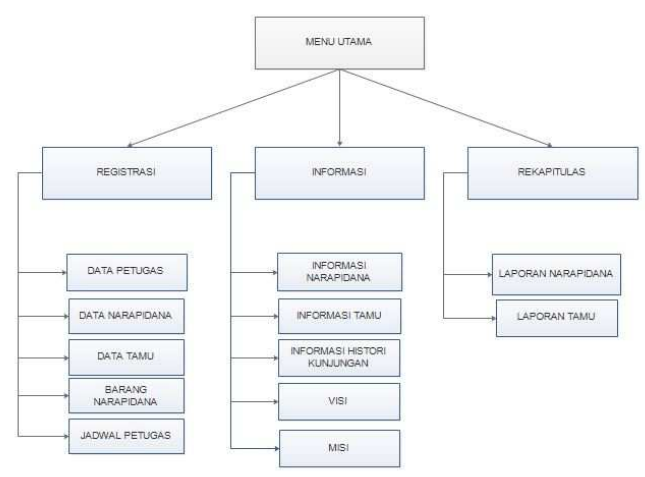

Gambar 3. Proses Hierarki

Gambar 3 menjelaskan tentang struktur menu dalam Sistem Informasi Lembaga Pemasyarakatan. Pada halaman utama terdapat menu registrasi, menu remisi, menu informasi, dan menu rekapitulasi. Dari menu-menu pada gambar 3 terdapat submenu yaitu pada registrasi terdapat submenu data petugas, data narapidana, data tamu, barang bawaan narapidana dan jadwal petugas. Pada menu informasi terdapat submenu informasi narapidana, informasi tamu, informasi histori kunjungan, visi dan misi. Pada menu rekapitulasi terdapat sub menu laporan narapidana dan laporan tamu.

\subsection{Desain Flowchart Sistem}

a. Flowchart Proses Pemasyarakatan 


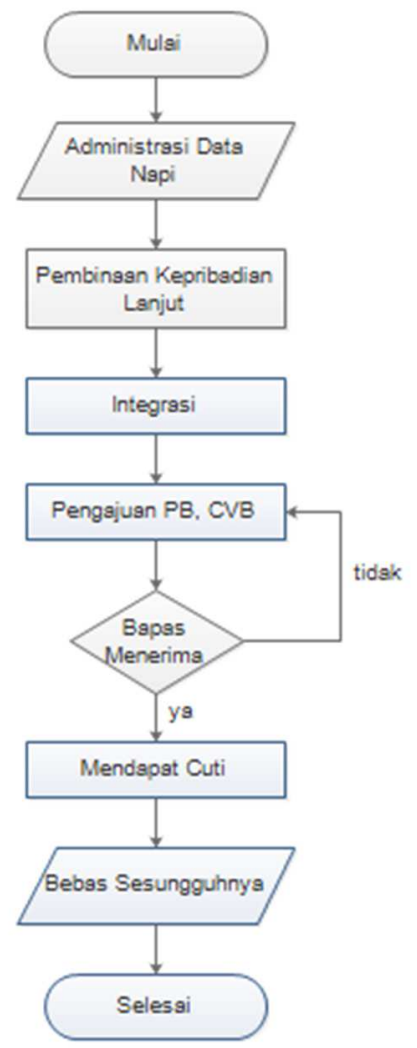

Gambar 4. Flowchart Proses Pemasyarakatan

Pada gambar 4 menerangkan ketika narapidana datang, maka akan dilakukan administrasi, setelah narapidana menjalani administrasi, narapidana akan menjalani proses pembinaan kepribadian dari lembaga pemsyarakatan. Setelah narapidana menjalani pembinaan kepribadian, narapidana akan menjalani proses asimilasi yaitu pembauran atau adaptasi dengan lingkungan serta membentuk karakter yang baru. Kemudian narapidana menjalani proses integrasi. Integrasi adalah kesempurnaan atau keseluruhan.

\section{b. Flowchart Prosedur Remisi}

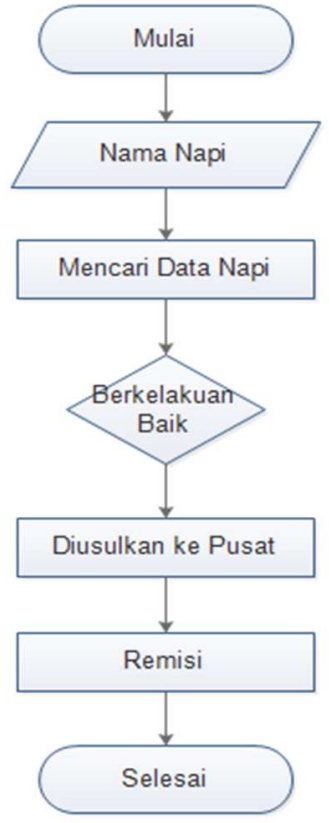

Gambar 5. Flowchart Prosedur Remisi Narapidana

Gambar 5 menjelaskan tentang alur pengurangan masa tahanan atau remisi narapidana. Petugas memasukkan nama narapidana kedalam barang pencarian, apabila narapidana yang akan diusulkan ke Bapas tidak ada catatan pelanggaran, maka petugas akan membuatkan surat, sedangkan kalau narapidana banyak catatan pelanggaran, maka petugas tidak berhak memberikan surat. Setelah narapidana yang berkelakuan baik selama didalam tahanan berkelakuan baik mendapat remisi, maka petugas akan mengurangi masa tahanan berdasarkan remisi yang diberikan oleh Bapas.

\subsection{Desain Database}

a. Data Flow Diagram (DFD)

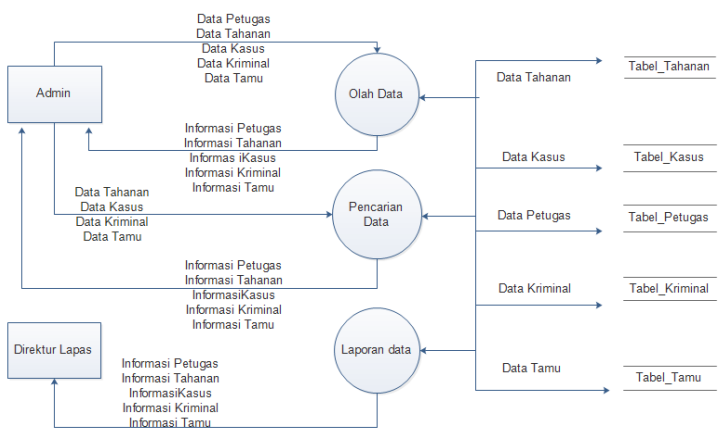

Gambar 6. Data Flow Diagram

Data flow diagram pada gambar 6 merupakan bagan alir karena menggambarkan secara umum tentang proses sistem informasi yang nantinya akan dikerjakan. DFD 
menjelaskan tentang gambaran umum mengenai Sistem Lembaga Pemsyarakatan yang terjadi hubungan timbal balik antara petugas dengan sistem informasi dan hubungan timbal balik antara pemimpin dengan sistem informasi.

\section{b. Conceptual Data Model (CDM)}

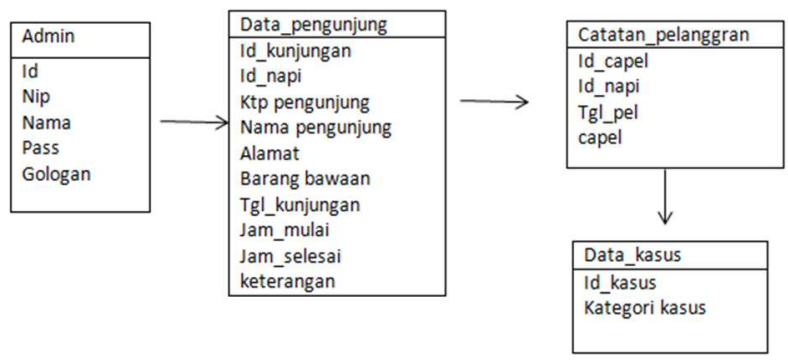

Gambar 7. Conceptual Data Model

\subsection{Rancangan AntarMuka}

1. Rancangan Antarmuka Halaman login

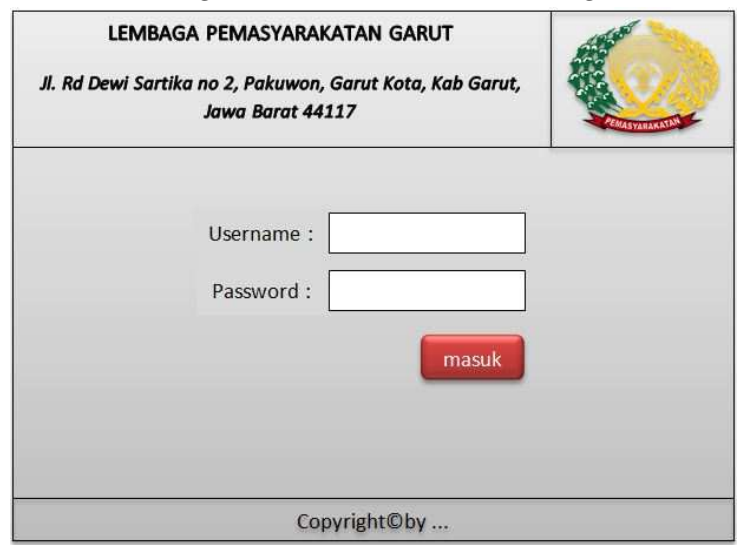

Gambar 8. Rancangan Halaman Login Sistem Lapas Menggambarkan halaman utama pada saat membuka website, yang berisikan menu untuk masuk sistem oleh petugas.

2. Rancangan Halaman Utama

\begin{tabular}{|c|c|c|c|}
\hline \multicolumn{3}{|c|}{$\begin{array}{l}\text { LEMBAGA PEMASYARAKATAN GARUT } \\
\text { J. Rd Dewi Sartika no 2, Pakuwon, Garut Kota, Kab Garut, } \\
\text { Jawa Barat } 44117\end{array}$} & $66^{\circ}$ \\
\hline Data Petugas & Data Napi & Data Tamu & Laporan \\
\hline \multicolumn{4}{|l|}{ Visi...................... } \\
\hline \multicolumn{4}{|c|}{ Misi.............................. } \\
\hline \multicolumn{4}{|c|}{ Copyright@by ... } \\
\hline
\end{tabular}

Gambar 9. Rancangan Halaman Utama Menggambarkan halaman utama pada saat membuka website, yang berisikan menu data petugas, narapidana, pengunjung/tamu dan laporan..

3. Rancangan Halaman Data Petugas

LEMBAGA PEMASYARAKATAN GARUT
J. Rd Dewi Sartika no 2, Pakuwon, Garut Kota, Kab Garut,
Jawa Barat 44117

Gambar 10. Rancangan Halaman Menu Petugas Menu petugas digunakan untuk mencatat data-data petugas dan sebagainya yang dicatat.

4. Rancangan Halaman Registrasi dan Data Tahanan

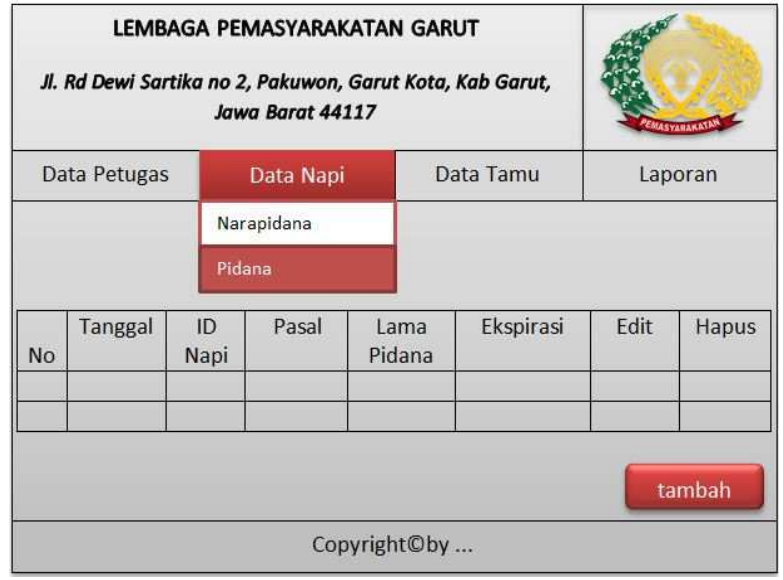

Gambar 11. Rancangan Halaman data Tahanan 


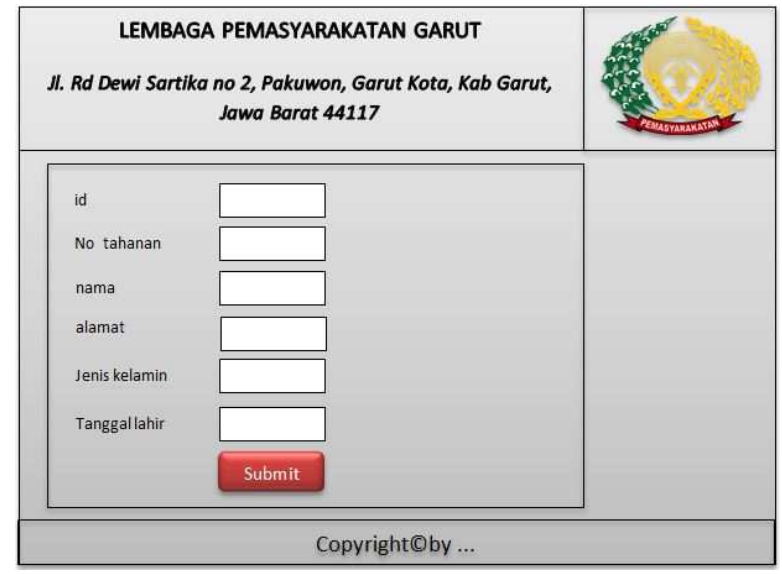

Gambar 12. Rancangan Halaman Registrasi Data Tahanan

Menu registrasi narapidana digunakan untuk mencatat data-data penting narapidana, termasuk data keluarga dan data alamat.

5. Rancangan Halaman Registrasi dan Data Napi

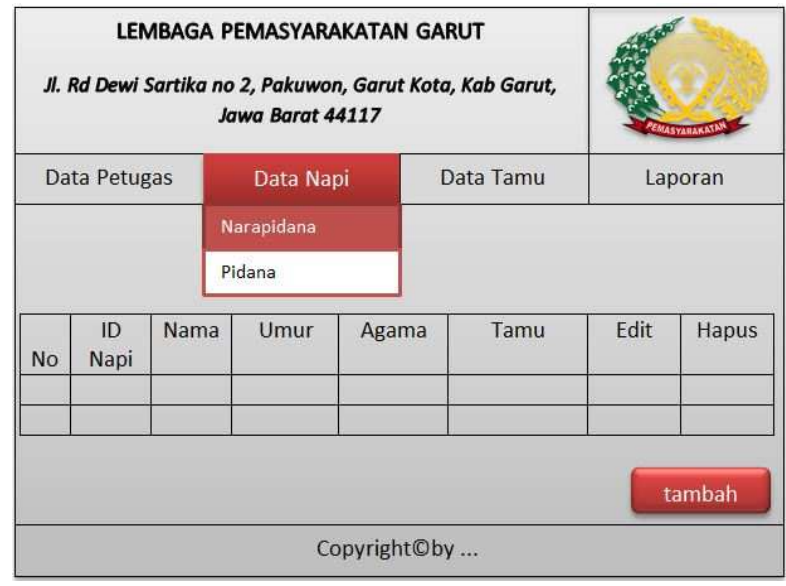

Gambar 13. Rancangan Halaman Data Narapidana

6. Rancangan Halaman Data Tamu

\begin{tabular}{|c|c|c|c|c|c|c|c|}
\hline \multicolumn{6}{|c|}{$\begin{array}{l}\text { LEMBAGA PEMASYARAKATAN GARUT } \\
\text { J. Rd Dewi Sartika no 2, Pakuwon, Garut Kota, Kab Garut, } \\
\text { Jawa Barat } 44117\end{array}$} & \multicolumn{2}{|c|}{$8^{6}$} \\
\hline \multicolumn{3}{|c|}{ Data Petugas } & \multicolumn{2}{|l|}{ Data Napi } & Data Tamu & \multicolumn{2}{|c|}{ Laporan } \\
\hline No & \begin{tabular}{c|} 
ID \\
Tamu
\end{tabular} & Nama & Alamat & Kota & No. telpon & Edit & Hapus \\
\hline 1 & TM01 & Adol & Tarogong & Garut & 081234567890 & Edit & Hapus \\
\hline & TM02 & Edon & Kopo & Bandung & 086789876543 & Edit & Hapus \\
\hline & & & & & & & \\
\hline & \multicolumn{7}{|c|}{ Copyright $\bigcirc$ by ... } \\
\hline
\end{tabular}

Gambar 14. Rancangan Halaman Data Tamu Menu registrasi pengunjung digunakan untuk mencatat data-data pengunjung beserta barang-barang bawaannya juga dicatat. Apabila pengunjung lebih dari satu orang, hanya satu pengunjung yang bertanggung jawab atas kunjungannya yang akan dicatat.

\section{HASIL DAN PEMBAHASAN}

4.1 Halaman Login

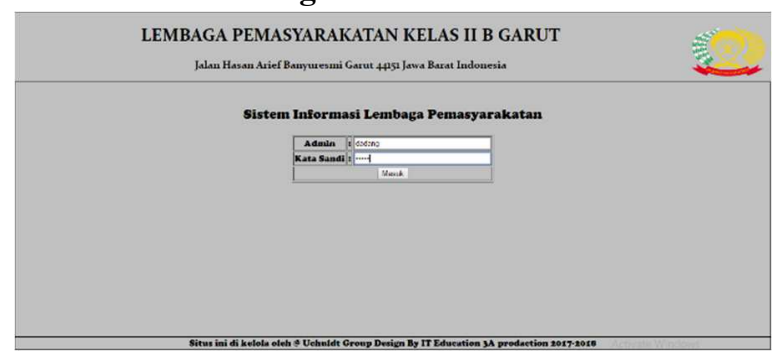

Gambar 15. Halaman Login Sistem

Langkah pertama untuk memsauki sistem, yaittu petugas yang sudah terdaftar didatabase petugas sebagai petugas pengguna sistem.

\subsection{Halaman Beranda Sistem}

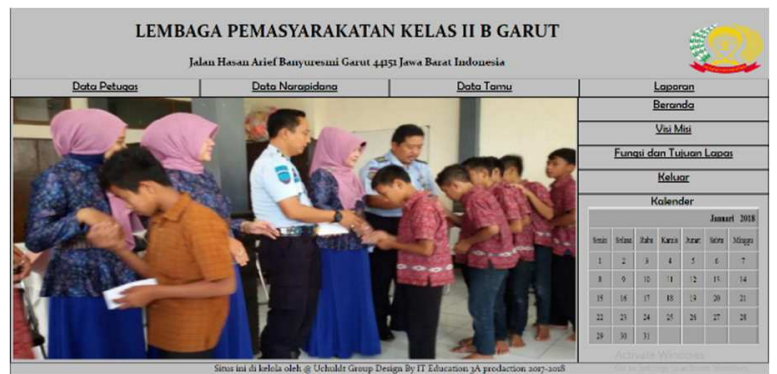

Gambar 16. Halaman Utama Sistem Lapas Halaman utama dari sistem yang dibuat, yang terdapat beberapa menu.

\subsection{Penginputan Data Petugas}

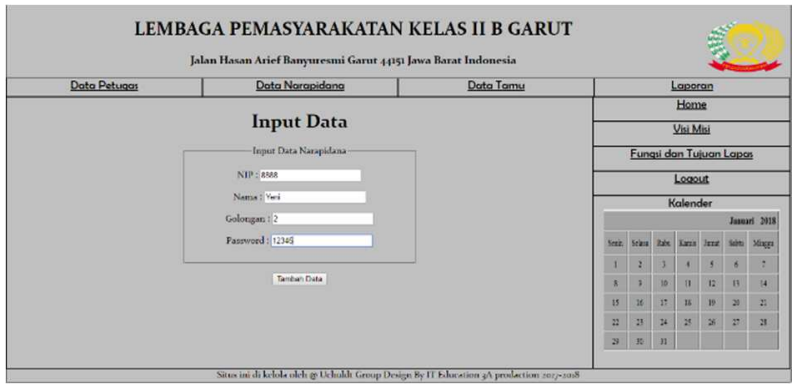

Gambar 17. Halaman Penginputan Data Petugas Halaman untuk melakukan penginputan data petugas.

\subsection{Data petugas}




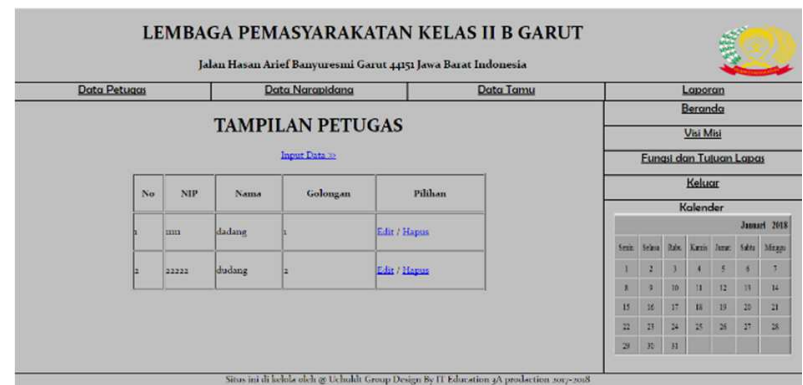

Gambar 18. Halaman Data Petugas

\subsection{Penginputan Data Narapidana}

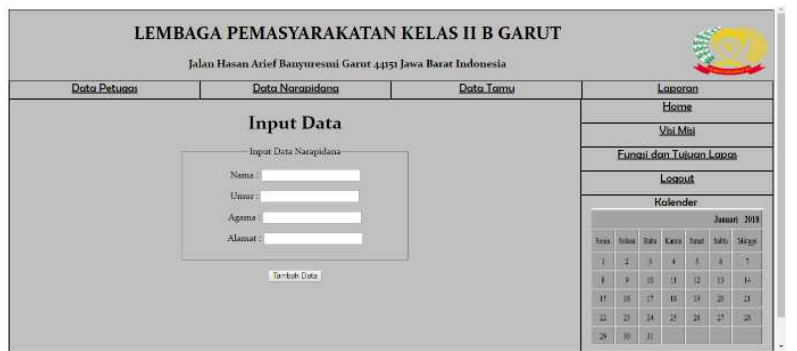

Gambar 19. Halaman Penginputan Data Narapidana Langkah pertama melakukan pemasukan-penginputan data narapidana yaitu petugas memasukkan nama narapidana ke dalam menu napi di halaman informasi data narapidana. Kemudian tekan tombol update data, maka akan keluar data narapidana.

\subsection{Data Narapidana}

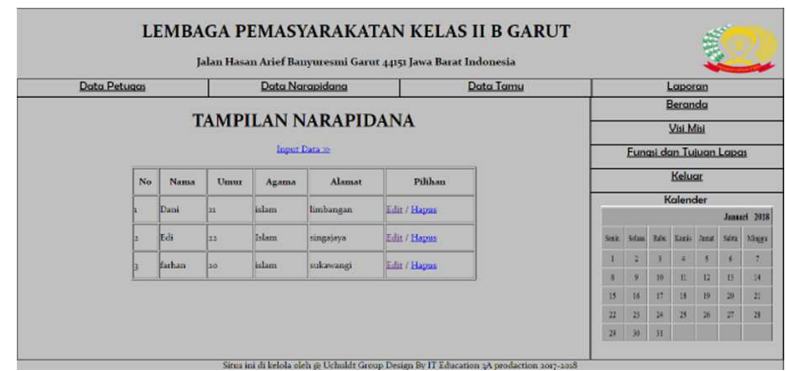

Gambar 20. Halaman Data Narapidana

Langkah pertama melakukan pengolahan data narapidana yaitu petugas memasukkan nama narapidana ke dalam menu napi di halaman informasi data narapidana. Kemudian tekan tombol nya, maka akan keluar data narapidana.

\subsection{Penginputan Data Tamu}

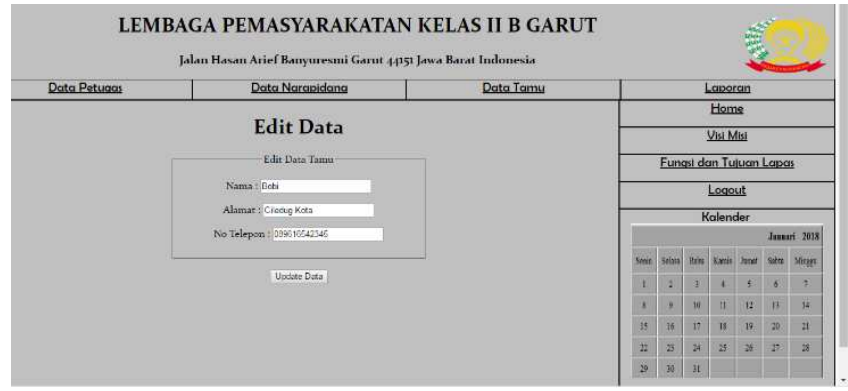

Gambar 21. Halaman Penginputan Data Tamu Halaman untuk menginputkan data tamu/pengun jung lapas.

\subsection{Data Tamu}

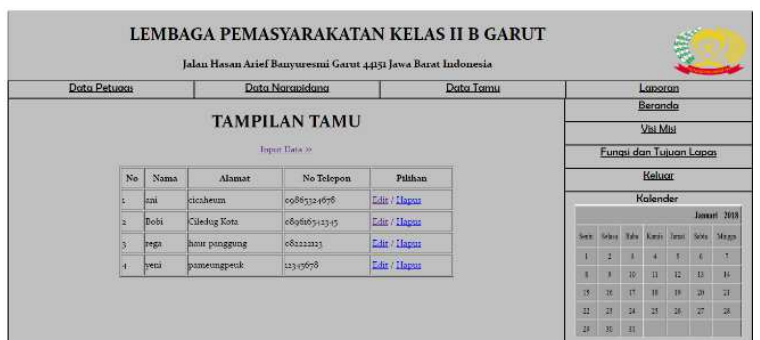

Gambar 22. Halaman Data Tamu

Halaman untuk menampilkan data tamu/data pengunjung yang suidah dicatat.

\subsection{Tampilan Laporan}

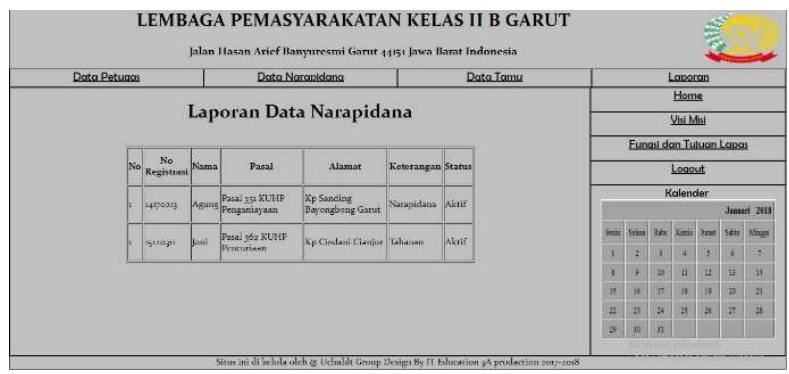

Gambar 23. Halaman Data Laporan

Halaman untuk menampilkan laporan data-data lapas kepada pemimpin.

\section{KESIMPULAN DAN SARAN \\ 5.1 Kesimpulan}

Dari hasil pembuatan Sistem Informasi Lembaga Pemsyarakatan dan laporan tugas akhir dapat dihasilkan beberapa kesimpulan, yaitu sebagai berikut :

1. Sistem Informasi Lembaga Pemasyarakatan dapat menangani proses pengolahan data narapidana dan data pengunjung di Lembaga Pemasyarakatan Kelas IIB Kota Garut dan dapat berjalan dengan baik sesuai dengan fungsi dan tujuan, meskipun sistem yang 
dibuat dan dirancang belum begitu sempurna dan masih sangat sederhana.

2. Sistem Informasi Lembaga Pemasyarakatan juga dapat mencetak informasi tentang data narapidana, dan informasi data pengunjung.

\subsection{Saran}

Karena sistem yang kami rancang masih sangat sederhana, maka untuk mengembangkan Sistem Informasi Lembaga Pemsyarakatan diharapkan ada banyak masukan dari banyak pihak, sehingga kami bisa memperbaiki dan mengembangan sistem yang lebih baik lagi.

\section{DAFTAR PUSTAKA}

[1] A Suryadi. 2015. Perancangan Aplikasi Tes Berbasis Komputer (Cbt) Menggunakan Pendekatan Terstruktur Untuk Penerimaan Mahasiswa Baru Di Perguruan Tinggi. Jurnal PETIK. Hal 68-81. Vol 1 2015.

[2] D Nurdiana, A Suryadi. Audit Sistem Informasi Untuk Meningkatkan Kapabilitas Proses Pada Sistem Informasi Akdemik Di Perguruan Tinggi Menggunakan Cobit 4.1 Berdasarkan Iso/Iec 15504 (Studi Kasus Stkip Garut). Seminar Nasional Hasil Penelitian Universitas Kanjuruhan Malang 2017. Hal 37-54.

[3] Kadir, Abdul. 2011. From Zero to A Pro: CSS. Yogyakarta: Andi Yogyakarta.

[4] Kristanto, Andri. 2010. Kupas Tuntas PHP \& MySQL. Klaten: Cable Book.

[5] Nugroho, Bunafit. 2008. Aplikasi Pemrograman Web Dinamis dengan PHP dan MySQL. Yogjakarta: GavaMedia.

[6] Shalahuddin, M. 2011. Modul Pembelajaran Rekayasa Perangkat Lunak (Terstruktur dan Berorientasi Objek). Bandung: Modula.

[7] Sigit, Aloysius. 2011. Website Super Canggih Dengan Plugin Jquery Terbaik. Jogjakarta: Mediakita.

[8] Sulhan, Moh. 2007. Pengembangan Aplikasi Berbasis Web dengan PHP dan ASP. Yogyakarta: Gava Media.

[9] Sutabri, Tata. 2012. Konsep Sistem Informasi. Yogjakarta: ANDI.

[10] Suryadi, Andri. "PERANCANGAN APLIKASI GAME EDUKASI MENGGUNAKAN MODEL WATERFALL." JURNAL PETIK 3.1 (2017): 8-13.

[11] Suryadi, Andri. "SISTEM REKOMENDASI PENERIMAAN MAHASISWA BARU MENGGUNAKAN NAIVE BAYES CLASSIFIER
DI

INSTITUT

PENDIDIKAN

INDONESIA." Joutica 3.2 (2018): 171-182.

[12] Suryadi, Andri, and Erwin Harahap. "Pemeringkatan Pegawai Berprestasi Menggunakan Metode AHP (Analytic Hierarchy Process) di PT. XYZ." Matematika 16.2 (2017). 